\title{
Penilaian Kinerja Manager Pusat Pendapatan dalam Perspektif Akuntansi Pertanggungjawaban pada Perusahaan Daerah Perkebunan (PDP) Khayangan Jember
}

\author{
Ikmalus Sholihin ${ }^{1}$, Diyah Probowulan², Rendy Mirwan ${ }^{3}$
}

1,2,3Fakultas Ekonomi, Universitas Muhammadiyah Jember, Jawa Timur, Indonesia

\author{
A R T I C L E I N F O \\ Article history: \\ Received 19 August 2019 \\ Received in revised form \\ 16 September 2019 \\ Accepted 15 October 2019 \\ Available online 30 \\ November 2019

\section{Kata Kunci: \\ Penilaian Kinerja, \\ Akuntansi Akuntabilitas. \\ Manajer Pusat Pendapatan \\ Keywords: \\ Performance Appraisal \\ Accountability Accounting. \\ Reveneu Center Manager} kinerja manajer pendapatan pusat kurang optimal, dengan persentase pendapatan perusahaan berfluktuasi dari 2015-2018. Penyebab fluktuasi pendapatan perusahaan adalah pertama bahwa manajemen produksi kurang tepat dalam memprediksi iklim dan cuaca sehingga mempengaruhi target produksi yang direncanakan, kedua manajer pemasaran tidak pandai membaca pasar

\section{A B S T R A C T}

The phenomenon in this study is to see the development of this company from 2015 fluctuating so that the target of a company is less than optimal. Therefore PDP Kalimarasawan requires production and marketing management as a revenue center, where the task of production and marketing management is to predict the production target and promote the company's products, make sales forecasts and analyze the market, with the aim that the company's goals can be achieved namely profit and can be superior among competing companies engaged in the same industry. Methods of data collection are carried out in various settings, various sources, and various ways and in general there are four techniques of data collection, namely: observation, interviews, documentation and triangulation / combination. Systematic analysis of data obtained from interviews, field notes, and other materials, so that they can be easily understood, and findings can be informed to others. The results showed that the performance of the central revenue manager was less than optimal, with a percentage of fluctuating corporate income from 2015-2018. The fluctuating causes of corporate earnings are first that production management is less precise in predicting climate and weather so that it affects the planned production target, both marketing managers are not very good at reading market share. Suggestions for revenue center managers must be visionary in preparing the realization of production, budget, and predicting sales prices in order to achieve the company's vision and mission.

\footnotetext{
Corresponding author.

E-mail addresses: ikmalussholihin@gmail.com (Ikmalus Sholihin) 


\section{Pendahuluan}

Akuntansi pertanggungjawaban merupakan suatu sistem yang disusun sedemikian rupa sesuai dengan sifat dan kegiatan perusahaan dengan tujuan agar masing-masing unit organisasi dapat mempertanggungjawabkan hasil kegiatan unit yang berada di bawah pengawasannya (Sriwidodo, 2010)Pelaksanaan pertanggungjawaban ini harus dilakukan secara objektif karena menjadi salah satu penentu kebijakan perusahaan di masa depan. Pelaporan pertanggungjawaban juga berfungsi sebagai salah satu alat penilaian kinerja atau prestasi terhadap para manajer tingkat bawah. Akuntansi pertanggungjawaban merupakan salah satu konsep dari akuntansi manajemen yang berkaitan dengan pusat pertanggungjawaban dalam sebuah organisasi. Akuntansi pertanggungjawaban menelusuri biaya, pendapatan, laba, dan investasi dalam setiap unit organisasi dimana setiap unit organisasi merupakan suatu pusat pertanggungjawaban yang dipimpin oleh seorang manajer. Akuntansi petanggungjawaban mendasarkan pada pemikiran bahwa seorang manajer harus bertanggung jawab terhadap kinerjanya dan kinerja bawahannya.Konsep akuntansi pertanggungjawaban menjadi pedoman bagi departemen akuntansi dalam mengumpulkan, mengukur, dan melaporkan kinerja sesungguhnya, kinerja yang diharapkan, dan selisih yang terjadi pada setiap pusat pertanggungjawaban. Akuntansi pertanggungjawaban bukan hanya menunjukkan besarnya penyimpangan realisasi dan anggaran yang terjadi, tetapi yang terutama adalah, untuk memberikan informasi yang digunakan para manajer pusat pertanggungjawaban dalam melaksanakan tanggungjawab. Melalui informasi ini diharapkan dapat mendorong para manajer untuk mengambil tindakan langsung yang diperlukan dalam memperbaiki prestasi kerja sesuai tujuan perusahaan tercapai yaitu memperoleh keuntungan (profit) yang optimal.

Perusahaan Daerah Perkebunan disebut (PDP) Kebun Kalimrawan merupakan Badan Usaha Milik Daerah (BUMD) milik Pemerintahan Kabupaten Jember sejak tahun 1969 yang bergerak dibidang Perkebunan, dalam mengemban misinya, kedudukan PDP merupakan perusahaan daerah yang keberdaannya di bawah kendali Pemerintah Kabupaten Jember, terutana Bupati. Hal ini berdasarkan pada Peraturan Daerah No 2 Tahun 2012. PDP merupakan salah satu BUMD penyumbang Pendapatan Asli Daerah (PAD) yang terebesar dibanding BUMD lain yang dimiliki Kabupaten Jember. PDP memiliki jumlah sumbangan kepada Pendapatan Asli Daerah (PAD) dengan jumlah terbanyak. Hal ini menunjukan bahwa PDP merupakan yang besar dan menjadi kebanggaan Kabupaten Jember. Dalam beberpa tahun terakhir PDP mengalami penurunan kemampuan menyumbangkan ke PAD Kabupaten Jember. Untuk tahun 2015 PDP dikabarkan tidak mampu memberikan sumbangan ke PAD Kabupaten Jember.

Fenomena dalam penelitian ini adalah melihat pada perkembangan perusahaan ini dari 2015 mengalami fluktuatif sehingga target suatu perusahaan kurang maksimal. Oleh karena itu PDP Kebun Kalimrawan memerlukan departemen penjualan sebagai pusat pendapatan, dimana tugas dari manajer penjualan tersebut adalah untuk mempromosikan produk perusahaan, membuat ramalan penjualan serta menganalisa pasar. Perusahaan untuk dapat meningkatkan kinerjanya khususnya manajer penjualan dengan maksud agar tujuan perusahaan dapat tercapai yaitu memperoleh laba dan dapat lebih unggul diantara perusahaan pesaingnya yang bergerak di industri yang sama.

Berdasarkan dari penjelasan yang disimpulkan bahwa akuntansi pertanggungjawaban merupakan hal yang penting dalam suatu perusahaan. Penerapan akuntansi pertanggungjawaban dapat menunjang tercapainya tujuan suatu perusahaan dan akuntansi pertanggungjawaban memiliki peran yang penting dalam menilai prestasi manajemen terutama dilihat dari kinerja para manajer yang berada disetiap pusat pertanggungjawaban tersebut. Penilaian kinerja yang digunakan dalam penelitian ini adalah kinerja manajer pusat pendapatan yang berada pada PDP Kebun Kalimrawan.

Berdasarkan hasil survey prapenelitian, didapatkan informasi kinerja PDP Kebun Kalimrawan 4 tahun teakhir. Kinerja tersebut dapat dilihat pada tabel di bawah ini:

Tabel: 1. Presentase Pendaptan PDP Kalimrawan

\begin{tabular}{ccc}
\hline No & Tahun & Pendapatan \\
\hline 1 & 2015 & $\mathbf{2 6 \%}$ \\
2 & 2016 & $\mathbf{2 2 \%}$ \\
3 & 2017 & $\mathbf{4 6 \%}$ \\
4 & 2018 & $\mathbf{2 7 \%}$ \\
\hline
\end{tabular}

Berdasarkan data tersebut, dapat disimpulkan bahwa terjadi fluktuasi kinerja PDP Kalimrawan. Hal ini perlu dikaji lebih mendalam untuk mengetahui penyebab terjadi fluktuasi kinerja PDP Kebun Kalimrawan tersebut, khususnya dengan pendekatan akuntansi pertanggungjawaban. 
Persamaan dengan penelitian sebelumnya adalah membahas akuntansi pertanggungjawaban dan pengendalian biaya, sedangkan letak perbedaannya adalah pada data dan objek penelitian.Objek dari penelitian ini adalah PDP Kebun Kalimrawan.

Dari uraian di atas, maka perlu peneliti memandang bahwa akuntansi pertanggungjawaban merupakan hal yang penting untuk diterapkan karena dapat menunjang pencapaian tujuan umum perusahaan dan membantu pihak manajemen dalam menyusun kebijaksanaan perusahaan dimasa yang akan datang dan akuntansi pertanggungjawaban mempunyai peranan dalam menilai prestasi manajemen, maka perlu dilakukan penelitian tentang bagaimana keberadaan dan penerapan akuntansi pertanggungjawaban pada PDP Kebun Kalimrawan. Oleh karena itu, penulis tertarik untuk melakukan penelitian mengenai akuntansi pertanggungjawaban dengan judul: "Penilaian Kinerja Manager Pusat Pendapatan dalam Perspektif Akuntansi Pertanggungjawaban Pada PDP Kebun Kalimrawan”.

\section{Metode}

Jenis penelitian ini berdasarkan karakteristik masalahnya termasuk dalam kategori penelitian kualitatif yaitu metode penelitian yang berlandaskan pada filsafat postsitivisme/enterpretif, digunakan untuk meneliti pada kondisi objek yang alamiah, (sebagai lawannya adalah eksperimen) dimana peneliti sebagai instrumen kunci, teknik pengumpulan data dilakukan secara trianggulasi (gabungan). Dan penelitian menggunakan pendekatan analisis deskriptif, yaitu prosedur pemecahan masalah yang diselidiki dengan menggambarkan atau melukiskan keadaan subyek atau obyek penelitian (seseorang,lembaga,masyarakat dan lain-lain) pada saat sekarang berdasarkan fakta-fakta yang tampak atau sebagaimana adanya (Sugiyono,2014:28).

Objek penelitian ini adalah PDP Kalimrawan Kabupaten Jember. Fenomena dalam penelitian ini adalah melihat pada perkembangan perusahaan ini dari 2016 hingga 2018 mengalami fluktuatif sehingga target suatu perusahaan kurang maksimal. Perusahaan tersebut memiliki potensi untuk mempengaruhi perekonomian Indonesia, khususnya Kebupaten Jember melalui pengelolaan aset hutan.

Adapun sumber data yang yang digunakan dalam penelitian ini adalah sebagai berikut:

1. Data primer

Data primer merupakan sumber data penelitian yang diperoleh secara langsung dari sumber asli (tidak melalui madia perantara) (Indriantoro dan Supomo, 2002:146). Data primer ini berupa teks hasil wawancara dan diperoleh melalui wawancara dengan informan yang sedang dijadikan sampel dalam penelitian. Dalam penelitian ini data primer diperoleh memalui informan yaitu dari manajer keuangan, manajer kantor dan umum.

2. Data sekunder

Data sekunder merupakan sumber data penelitian yang diperoleh peliti secara tidak langsung melalui media perantara (diperoleh dan dicatat oleh pihak lain) (Indriantoro dan Supomo, 2002:147). Data sekunder berupa data-data yang sudah tersedia dan dapat diperoleh dengan cara membaca, melihat atau mendengarkan. Data ini berasal dari primer yang sudah diolah sebelumnya. Dan dalam penelitian ini data sekunder yang digunakan ialah berupa laporan keuangan PDP Kalimrawan Kab Jember.

Metode pengumpulan data adalah langkah yang paling utama dalam penelitian, tanpa mengetahui teknik pengumpulan data, maka tidak akan didapatkan data yang memenuhi standart data yang ditetapkan. Pengumpulan data dapat dilakukan dalam berbagai setting, berbagai sumber, dan berbagai cara. Dan secara umum terdapat empat teknik pengumpulan data yaitu : observasi, wawancara, dokumentasi dan trianggulasi/gabungan. Penelitian ini metode pengumpulan data yang digunakan adalah:

Analisis data adalah proses mencari dan menyusun secara sistematis data yang diperoleh dari hasil wawancara, catatan lapangan, dan bahan-bahan lain, sehingga dapat mudah difahami, dan temuannya dapat diinformasikan kepada orang lain. Analisis data dilakuikan dengan mengorganisasikan data, menjabarkannya ke dalam unit-unit, melakukan sintesa, menyusun kedalam pola, memilih mana yang penting dan yang akan dipelajari, dan membuat kesimpulan yang dapat diceritakan kepada orang lain (Bogdan). Didialam penelitian ini digunakan analisis deskriptif kualitatif, dimana peneliti akan memberikan gambaran mengenai penilaian kinerja PDP Kalimrawan dari sudut pandang Akuntansi Pertanggung Jawaban:

1. Pengumpulan data

2. Penganalisisan akuntansi pertanggungjawaban antara lain: Struktur organisasi, Proses anggaran, Anggaran dan realisasi pendapatan perusahaan, Penilaian kinerja pusat pendapatan

Adapun tahapan analisis data dalam perspektif akuntansi pertanggungjawaban pada PDP Kalimrawan Kabupaten Jember, terdiri dari: Reduction Data (reduksi data), mereduksi data berarti merangkum 
dan memilih hal- hal pokok, memfokuskan pada hal-hal yang penting, dicari tema dan polanya. Dengan demikian data yang direduksi akan memberikan gambaran yang jelas dan mempermudah peneliti untuk melakukan pengumpulan data selanjutnya. Display data (penyajian data), dari hasil reduksi yang dilakukan peneliti menampilkan data- data yang berkaitan dan berhubungan ataupun menjawab permasalahan yang diteliti. Conclusion Drawing / Verification, dalam penelitian ini peneliti mencoba menemukan atau keterkaitan antara data-data yang diperoleh dan analisis yang dilakukan.

3. Menindaklanjuti hasil evaluasi dan membuat rekomendasi

4. Menarik kesimpulan penelitian yang dilakukan oleh peneliti.

\section{Hasil dan Pembahasan}

PDP Kahyangan Jember merupakan salah satu Badan Usaha Milik Daerah yang dimiliki Pemerintah Kabupaten Jember bergerak pada bidang perkebunan. Lokasi dari Perusahaan Daerah Perkebunan Kahyangan Jember yaitu di Jalan Gajahmada No. 245 Jember. Status PDP Kahyangan Jember BUMD yaitu sesuai Peraturan Daerah No. 1 Tahun 1969 tanggal 12 Februari 1969. Untuk mewujudkan Perusahaan Daerah Perkebunan Kahyangan Jember menjadi perusahaan yang mampu memberikan kontribusi Pendapatan Asli Daerah (PAD) Kabupaten Jember, adapun visi dan misi perusahaan yaitu:

Visi: Mewujudkan Perusahaan Daerah Perkebunan yang Berdaya Saing dan Terpercaya Misi: 1. Pengelolaan Usaha yang berdaya saing dan berdaya guna, 2. Pengembangan potensi sumberdaya kebun dan sumberdaya manusia, dan 3. Memberikan manfaat bagi lingkungan.

Setiap pendirian perusahaan selalu mempunyai tujuan yang ingin dicapai, upaya pencapaian tujuan tersebut menuntut adanya kerjasama dan keterlibatan setiap tenaga kerja seperti perusahaan lain pada umumnya. Adapun Perusahaan Daerah Perkebunan (PDP) Kahyangan Jember memiliki tujuan yaitu:

1. Menjadikan PDP Kahyangan Jember sebagai Perusahaan Daerah yang menjadi salah satu sumber Pendapatan Asli Daerah PAD dan sebagai sarana pengembangan perekonomian dalam rangka pembangunan daerah yaitu dengan meningkatkan produktifitas untuk meningkatkan pendapatan daerah.

2. Menciptakan lapangan kerja bagi pendapatan sekitar kebun lewat pemeliharaan tanaman dan peningkatan produksi yang diharapkan dapat meningkatkan kesejahteraan penduduk di sekitar kebun.

3. Melestarikan dan meningkatkan kesuburan tanah perkebunan yang berwawasan lingkungan. Struktur organisasi merupakan hal yang sangat diperlukan untuk mendapatkan gambaran mengenai pola hubungan antara bidang kerja maupun wewenang, dan tanggung jawab setiap komponen dalam penentuan sistem koordinasi dan kerjasama.

Struktur organisasi merupakan hal yang sangat diperlukan untuk mendapatkan gambaran mengenai pola hubungan antara bidang kerja maupun wewenang, dan tanggung jawab setiap komponen dalam penentuan sistem koordinasi dan kerjasama. Bagan struktur organisasi Perusahaan Daerah Perkebunan Kahyangan Kebun Kalimrawan Jember, yaitu:

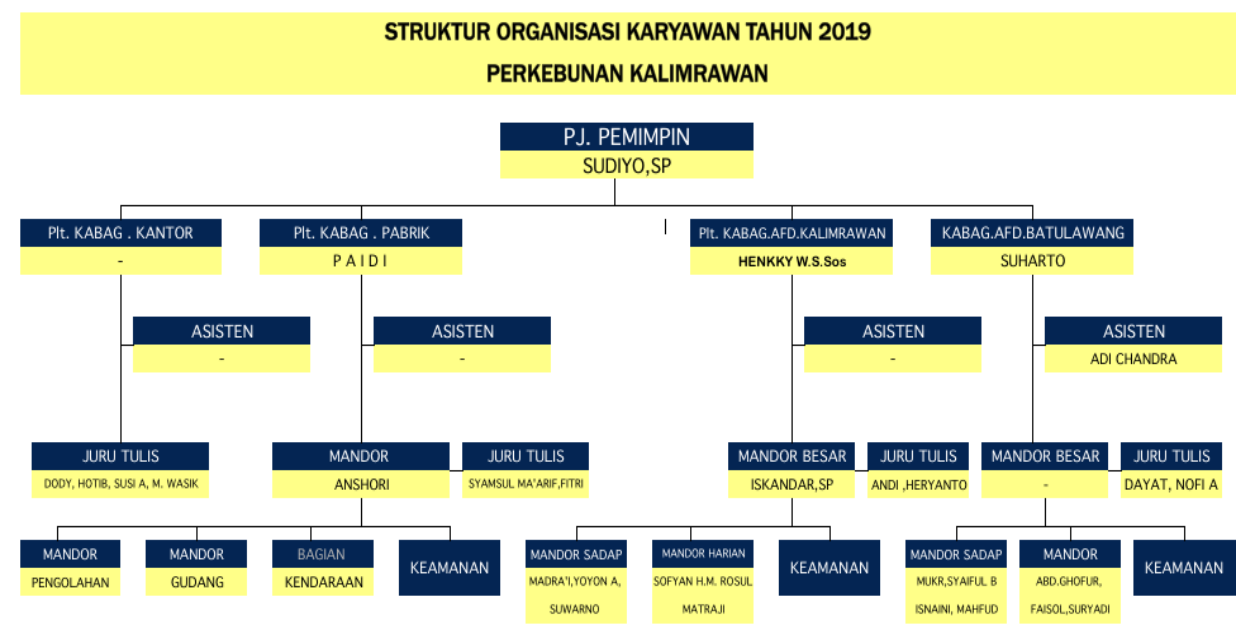

Sumber: PDP Kahyangan Jember 2019

Gambar 1. Struktur Organisasi Perusahaan 
Adapun tugas dan wewenang dari setiap bagian dalam struktur organisasi di Perusahaan Daerah Perkebunan Kahyangan Jember Kebun Kalimrawan yaitu :

1. Pemimpin Kebun mempunyai tugas, yaitu :

a. Meningkatkan dan mengembangkan kualitas, kuantitas tanaman produksi.

b. Menyiapkan, menyusun, dan mengatur anggaran belanja kebun.

c. Mengembangkan komunikasi atau informasi internal dan eksternal.

d. Bertanggung jawab langsung kepada administratur.

e. Melaksanakan tugas-tugas yang diberikan oleh atasannya.

2. Kepala Kantor Kebun bertanggung jawab kepada Administratur atau Pemimpin Kebun masingmasing. Kepala Kantor mempunyai tugas, yaitu :

a. Melaksanakan proses administrasi, keuangan, produksi, dan material.

b. Menyiapkan dan membuat laporan tetap dan isidental baik internal maupun eksternal.

c. Mengkoordinir dan menyiapkan rencana anggaran masing-masing afdeling.

d. Melaksanakan tugas-tugas yang diberikan oleh administratur atau pemimpin kebun.

3. Kepala Bagian Pabrik bertanggung jawab kepada Administratur atau Pemimpin Kebun masingmasing. Kepala Bagian Pabrik mempunyai tugas, yaitu :

a. Meningkatkan, mengawasi dan memelihara barang bergerak, barang tidak bergerak, dan barang produksi.

b. Meningkatkan dan mengembangkan pengawasan, keamanan, keselamatan

kerja, hasil produksi, dan lingkungan pabrik.

c. Meningkatkan dan mengembangkan koordinasi, komunikasi atau informasi

internal maupun eksternal.

d. Melaksanakan tugas-tugas yang diberikan oleh administratur atau pemimpin kebun.

4. Kepala Bagian Afdeling bertanggung jawab kepada Administratur atau Pemimpin Kebun masingmasing. Kepala Bagian Afdeling mempunyai tugas, yaitu :

a. Meningkatkan dan mengembangkan kualitas, kuantitas tanaman, produksi

dan areal kebun.

b. Mengadministrasikan dan mengawasi blok-blok baik teknis, non teknis, berkala maupun isidental.

c. Meningkatkan dan mengembangkan koordinasi, komunikasi atau informasi internal maupun eksternal.

d. Melaksanakan tugas-tugas yang diberikan oleh Pemimpin Kebun.

5. Mandor Kepala mempunyai tugas, yaitu:

a. Mengkoordinasikan mandor-mandor blok.

b. Memelihara dan bertanggung jawab atas keamanan, keselamatan dan

kelestarian lingkungan blok.

c. Meningkatkan dan mengembangkan kualitas dan kuantitas tanaman serta

tanah di lingkungan blok.

d. Mengadministrasikan, melaporkan kegiatan kebun baik teknis, non teknis, berkala maupun isidental.

f. Mengembangkan komunikasi atau informasi internal dan eksternal.

g. Melaksanakan tugas-tugas yang diberikan oleh atasannya.

\section{A. Analisis Penyusunan Anggaran, Target dan Realisasi Produksi Pada Pusat Pendapatan Perusahaan}

Proses penyusunan target realisasi dan anggaran merupakan langkah awal dan faktor penting sebelum perusahaan menghitung estimasi perolehan laba melalui penjualan produk yang dilakukan. Pada target penjualan termuat informasi mengenai Pemeliharaan tanaman, biaya panen, biaya pengolahan dan biaya pengiriman yang telah dianggarkan. Hal ini memungkinkan perusahaan untuk menaksir jumlah pendapatan yang mungkin akan terealisasi pada tahun tersebut. Oleh karena itu, perusahaan dituntut untuk mampu menyusun target pendapatan serealistis mungkin dan juga dengan mempertimbangkan beberapa faktor seperti biaya operasional, volume penjualan dan seberapa besar target atas penjualan yang telah dicapai pada tahun sebelumnya untuk menentukan target pendapatan di masa yang akan datang.

Berikut ini daftar anggaran dan realisasi pertanggungjawaban kas tahunan karet dan kopi pada PDP kebun Kalimrawan periode 2015-2018: 
Tabel 2. Daftar Anggaran dan Realisasi Pertanggungjawaban kas Tahunan Periode 2015-2018

\begin{tabular}{ccccc}
\hline No & Tahun & Anggaran & Realisasi & Penyimpangan \\
\hline 1 & 2015 & $3.817 .458 .500,00$ & $2.724 .015 .152,00$ & $29 \%$ \\
2 & 2016 & $3.823 .601 .700,00$ & $3.231 .131 .348,00$ & $15 \%$ \\
3 & 2017 & $4.108 .901 .950,00$ & $2.970 .337 .277,00$ & $28 \%$ \\
4 & 2018 & $3.468 .777 .458,00$ & $3.034 .095 .934,00$ & $13 \%$ \\
\hline
\end{tabular}

Sumber: Juru tulis PDP Kebun Kalimrawan

Tabel 3. Daftar Anggaran dan Realisasi Pertanggungjawaban kas Tahunan Periode 2015-2018

\begin{tabular}{ccccc}
\hline No & Tahun & Anggaran & Realisasi & Penyimpangan \\
\hline 1 & 2015 & $763.206 .800,00$ & $376.635 .878,00$ & $51 \%$ \\
2 & 2016 & $619.574 .200,00$ & $352.450 .261,00$ & $43 \%$ \\
3 & 2017 & $1.243 .874 .400,00$ & $773.615 .185,00$ & $38 \%$ \\
4 & 2018 & $956.303 .553,00$ & $710.082 .956,00$ & $26 \%$ \\
\hline
\end{tabular}

Sumber: Juru Tulis PDP Kebun Kalimrawan

Pada proses penyusunan target realisasi produksi, tugas seorang manajer pusat pendapatan menyusun strategi bagaimana proses target dan realisasi produksi dapat memenuhi target yang diharapkan perusahaan. Selanjutnya manager pusat pendapatan yang bertanggungjawab dalam proses tersebut.

Langkah yang digunakan PDP Kahyangan Jember dalam menentukan penyusunan strategi ralisasi anggaran dan target produksi sudah tepat. Hal ini disebabkan manager pusat pendatan melakukan evaluasi terlebih dahulu sebelum melakukan langkah yang akan dilaksanakan. Langkah ini dapat digunakan sebagai langkah antisipasi dalam melaksanakan kegiatan ataupun program yang telah direncanakan, dimana apabila program penjualan yang telah dijalankan pada tahun sebelumnya mampu menunjang target penjualannya maka program tersebut dapat dilanjutkan dan apabila program pada tahun sebelumnya dirasa kurang berhasil maka akan dilakukan program baru sebagai terobosan dalam penjualan.

\section{B. Analisis Anggaran dan Realisasi Pendapatan}

Laporan pertanggungjawaban pusat pendapatan yang akan dianalisis adalah anggaran dan realisasi pendapatan PDP Kahyangan Jember pada tahun 2015 hingga 2018. Pada umumnya laporan pertanggungjawaban pendapatan meliputi anggaran, realisasi dan selisih yang terjadi pada tahun tersebut. Tujuan utama dari analisis ini adalah agar dapat dilakukan penilaian kinerja terhadap manajer dan karyawan yang terkait dalam pusat pertanggungjawaban pendapatan. Penilaian kinerja yang dilakukan adalah untuk memotivasi para manajer dan seluruh karyawan yang berada pada perusahaan sehingga mampu meningkatkan nilai perusahaan untuk kedepannya.

Penilaian kinerja yang dilakukan oleh PDP Kahyangan Jember dengan menggunakan target penjualan sebagai salah satu alat evaluasi kinerjanya. Hal ini dilakukan dengan cara menganalisis dan membandingkan antara target penjualan dengan realisasi penjualan, dan dari hasil perbandingan tersebut akan diperoleh selisih yang disebut dengan penyimpangan dari target dan realisasinya. Penyimpangan atau selisih dari target penjualan dan realisasi penjualan dapat bersifat menguntungkan maupun merugikan bagi perusahaan. Dari selisih yang diperoleh kemudian akan dilakukan analisis lebih lanjut untuk mengetahui penyebab terjadinya selisih tersebut.

Berikut adalah daftar Anggaran dan Realisasi Pendapatan produk karet dan kopi pada PDP kebun Kalimrawan untuk tahun 2015 hingga 2018.

Tabel 4. Daftar Target Anggaran dan Realisasi Pendapatan Tahunan Periode 2015-2018

\begin{tabular}{ccccc}
\hline No & Tahun & Anggaran & Realisasi Pendapatan & Penyimpangan \\
\hline 1 & 2015 & $2.724 .015 .152,00$ & $3.360 .252 .000,00$ & $23 \%$ \\
2 & 2016 & $3.231 .131 .348,00$ & $3.895 .400 .000,00$ & $20 \%$ \\
3 & 2017 & $2.970 .337 .277,00$ & $3.728 .846 .000,00$ & $25 \%$ \\
4 & 2018 & $3.034 .095 .934,00$ & $3.595 .220 .000,00$ & $18 \%$ \\
\hline
\end{tabular}


Berdasarkan Tabel 4 di atas, dapat diketahui bahwa penyimpangan antara anggaran dan realisasi pendapatan yang terjadi pada tahun 2015 sebesar 23\%. Hal ini berarti bahwa realisasi pendapatan meyimpang sebesar Rp. 636.236.848,00 dari anggaran. Jauhnya realita dengan harapan pendapatan pada tahun 2015 disebabkan oleh produk yang dihasilkan (karet) mengalami penurunan drastis, pertama PDP Kalimrawan khususnya produk (karet) hanya mendapatkan $160.012 \mathrm{Kg}$ dari target $200.000 \mathrm{Kg}$ mengapa demikian karena manager pusat pendapatan kurang tepat memprediksi target antara anggaran dan realisasi pendapatan. Pada target realisasi pendapatan ditahun 2016 manager pusat pendapatan tidak mampu mencapai target kembali dari pendapatan dan realisasi anggaran karena menurunnya penyimpangan sebesar 20\% dengan realisasi pendapatan yang menyimpang sebesar Rp. 664.268.652,00 dari anggaran. mengalami penurunan dikarenakan pertama tidak sesuainya target produksi dengan realisasi produksi yang ada, PDP Kalimrawan menargetkan kembali $200.000 \mathrm{Kg}$ dengan perolehan produksi $194.770 \mathrm{Kg}$, Kedua turunnya harga komoditas produk yang dihasilkan sehingga terjadi penurunan pendapatan yang segnifikan. Pada target realisasi pendapatan tahun 2017 terjadi kenaikan pendapatan karena naiknya penyimpangan yang cukup besar yaitu 25\%. Hal ini bahwa realisasi pendapatan menyimpang sebesar Rp. 758.508.723,00 dari anggaran. Keberhasilan pendapatan tahun 2017 disebabkan oleh harga komoditas produk (karet) yang naik segnifikandari periode sebelumnya. Pada tahun 2018 target anggaran dan realisasi pendapatan jauh dengan harapan karna turunnya penyimpangan yang sangat luar biasa yaitu $18 \%$ hal ini bahwa realisasi pendapatan menurun drastis deangn penyimpangan 561.124.066,00. Jauhnya realita dengan harapan pada pandapatan disebabkan turunnya harga komoditas karet secara nasional karena kondisi perdagangan dunia dalam sektor karet tidak stabil sehingga berdampak besar pada harga komoditas karet di indonesia.

Tabel 5. Daftar Target Anggaran dan Realisasi Pendapatan Tahunan Periode Tahun 2015-2018

\begin{tabular}{ccccc}
\hline No & Tahun & Anggaran & Realisasi Pendapatan & Penyimpangan \\
\hline 1 & 2015 & $376.635 .878,00$ & $573.364 .000,00$ & $52 \%$ \\
2 & 2016 & $352.450 .261,00$ & $484.000 .000,00$ & $37 \%$ \\
3 & 2017 & $773.615 .185,00$ & $1.759 .185 .000,00$ & $127 \%$ \\
4 & 2018 & $710.082 .956,00$ & $1.162 .644 .000,00$ & $63 \%$ \\
\hline
\end{tabular}

Tabel 5. memaparkan target antara anggaran dan realisasi pendapatan produk kopi ditahun 2015 PDP Kebun Kalimrawan mampu mencapai target disebabkan pendapatan yang naik segnifikan dari penyimpangan 52\% dengan selisih anggaran dengan pendapatan 196.728.122,00. Pada tahun 2016 PDP Kalimrawan mengalami penurunan pendapatan dengan penyimpangan 37\% yang mana selisih antara anggaran dan realisasi pendapatan 131.549.739,00, penyebab dari menurunnnya pendapatan disebabkan target dan realisasi produksi yang menurun. Pada tahun 2017 PDP Kalimrawan mengalami kenaikan yang sangat segnifikan karena mengalami kenaikan yang sangat drastis dari sebelumnya dengan penyimpangan $127 \%$ hal ini sesuai dengan yang diharapkan dengan penyimpangan pendapatan 985.569.815,00 mengapa demikian karena pertama target produksi sesuai prediksi yang direncanakan, kedua pada tahun 2017 harga komoditas kopi mengalami kenaikan yang segnifikan jika dibandingkan dengan tahun sebelumnya. Terakhir pada tahun 2018 PDP Kalimrawan mengalami penurunan kembali dengan penyimpangan $63 \%$ yang mana selisih antara anggaran dengan realisasi pendapatan 452.561.044,00 menurunnya pendapatan ini di sebabkan karena target dari realisasi produksi tidak sesuai harapan yaitu menurun dibandingkan sebelumnya tetapi harga komoditas kopi masih stabil hanya saja kurang tepatnya manager pusat pendapatan memprediksi musim sehingga berpengaruh kepada hasil produksi kopi.

Tabel 6. Daftar Target Anggaran dan Realisasi Pendapatan Tahunan Periode Tahun 2015-2018

\begin{tabular}{ccccc}
\hline No & Tahun & Anggaran & Realisasi Pendapatan & Penyimpangan \\
\hline 1 & 2015 & $3.100 .651 .030,00$ & $3.933 .616 .000,00$ & $26 \%$ \\
2 & 2016 & $3.583 .581 .609,00$ & $4.379 .400 .000,00$ & $22 \%$ \\
3 & 2017 & $3.743 .952 .462,00$ & $5.488 .031 .000,00$ & $46 \%$ \\
4 & 2018 & $3.744 .178 .890,00$ & $4.757 .864 .000,00$ & $27 \%$ \\
\hline
\end{tabular}

Tabel 6. memaparkan target dan realisasi pendapatan pada tahun 2015-2018. Pada daftar target dan ralisasi penjualan diatas terjadi fluktuatif setiap tahunnya oleh karna itu manager tidak mampu memenuhi target pendapatan produk karet dan kopi.Tabel diatas menjelaskan bahwa manager pusat pendapatan PDP Kalimrawan tidak memenuhi target pada tahun 2016 dan 2018 karna terjadi penurunan. 
Adapun penyebabnya tidak tercapainya target pendapatan tersebut adalah pertama turunnya harga komoditas produk, kedua tidak stabilnya iklim atau musim sehingga manajemen produksi tidak sesuai target dalam realisasi hasil produksi oleh karena itu manajemen produksi pandai membaca iklim dan musim agar hasil produksi sesuai dengan target yang diharapkan perusahaan, ketiga perusahaan harus bisa membaca pangsa pasar nasional maupun internasional karena kondisi pemasaran sangat menentukan keberlangsungan perusahaan kedepannya.

\section{Analisis Penilaian Kinerja Manager Pusat Pendapatan}

Perusahaan telah menetapkan laporan pertanggungjawaban pusat pendapatan sebagai dasar standar dalam menilai kinerja manajer pusat pendapatan. Penilaian kinerja memiliki tujuan pokok untuk memotivasi karyawan dalam mencapai sasaran organisasi dan dalam mematuhi standar perilaku yang telah ditetapkan sebelumnya, agar membuahkan tindakan dan hasil yang diinginkan. Penilaian kinerja yang dilakukan berdasarkan perbandingan antara target pendapatan dengan realisasi anggaran yang berada pada laporan pertanggungjawaban pada pusat pendapatan pada tahun 2015 hingga tahun 2018.

Hasil analisis laporan pertanggungjawaban pendapatan kemudian dapat dijadikan sebagai pedoman atau acuan untuk menetapkan target penjualan dan melakukan perbaikan-perbaikan pada periode yang akan datang. Sebagai tindak lanjut dari penilaian kinerja berdasarkan laporan pertanggungjawaban pusat pendapatan, PDP Kahyangan Jember telah menetapkan suatu kebijakan pemberian reward dan punishment. Kebijakan ini dilakunan dengan tujuan agar dapat memetoivasi dan memacu kinerja setiap personil yang berada dalam PDP Kahyangan Jember. Reward yang diberikan oleh Kantor Pusat dapat berupa insentif yang diberikan pada akhir tahun sedangkan untuk punishment yang diberikan adalah tidak mendapatkan insentif dan mendapatkan teguran serta akan dilakukannya evaluasi yang lebih intensif untuk target penjualan di periode berikutnya. Hal ini juga ditegaskan dengan pernyataan Pemimpin PDP Kebun Kalimrawan "perusahaan selalu melakukan evaluasi terhadap kinerja manajernya, biasanya evaluasi ini dilakukan setahun sekali. Dengan melihat average dari penjualan apakah telah memenuhi target atau tidak memenuhi target".

Jadwal pelaksanaan evaluasi dan penilaian kinerja yang dilakukan setiap 1 tahun sekali sudah cukup baik. Hal ini dikarenakan agar Kantor Pusat dapat melihat usaha dari manajer penjualan mengenai strategi apa yang dapat dilakukan untuk memenuhi target penjualan yang ditetapkan. Pemberian reward kepada manajer setelah dilakukannya evaluasi penilaian kinerja sudah sepantasnya didapatkan begitu pula dengan pemberian punishment kepada manajer apabila tidak dapat mencapai target penjualan sudah cukup baik. Pemberian punishment yang diberikan sudah sangat wajar, hal ini dikarenakan apabila perusahaan tidak dapat mencapai target penjualan yang ditetapkan bukan dikarenakan dari bagaimana team leader dan staf yang terkait diperusahaan tersebut tidak berusaha semaksimal mungkin dalam melaksanakan tugasnya tetapi juga terdapat beberapa faktor lain yang juga menjadi salah satu penyebab terjadinya penurunan target penjualan seperti pecahnya harga kompetitor yang berada di pasar yang sama.

\section{Simpulan dan Saran}

Berdasarkan hasil implementasi akuntansi pertanggungjawaban dalam penilaian kinerja manajer pusat pendapatan pada PDP Kebun Kalimrawan Jember yang telah dilakukan pada penelitian ini, maka dapat disimpulkan sebagai berikut: 1) Struktur organisasi pada PDP Kebun Kalimrawan Jember adalah Organisasi Fungsional, dimana terlihat jelas pemisahan tugas disetiap bagian yang ada dalam perusahaan telah terbagi berdasarkan fungsinya masing-masing tetapi dalam pelaksanaannya struktur organisasi belum dinyatakan baik karena masih terdapat pembagian tugas yang tumpang tindih antara bagian satu dengan yang lainnya. 2) Tujuan dari dibentuknya struktur organisasi adalah untuk mempermudah dalam pelaksanaanya tugas yang telah diberikan dan juga mempermudah manajemen untuk melakukan pengawasan terhadap setiap bidang yang ada pada PDP Kebun Kalimrawan Jember. 3) Dalam proses penyusunan target pendapatan, manager pusat pendapatan tidak turut serta dalam proses penyusunanya, manager pusat pendapatan hanya turut serta sampai proses melaporkan realisasi pendapatan yang telah tercapai ditahun tersebut. 4) Pada tahun 2016 dan 2018 perusahaan tidak dapat mencapai target pendapatan, hal ini disebabkan oleh beberapa faktor diantaranya: harga komoditas yang fluktuatif, tidak stabilnya iklim dan cuaca, sehingga internal perusahaan dalam mengatasi hal tersebut Pemimpin PDP Kebun Kalimrawan Jember melakukan evaluasi kinerja manager pusat pendapatan. 5) Penerapan akuntansi pertanggungjawaban dalam mengendalikan dan mengevaluasi kinerja manager pusat pendapatan PDP Kebun Kalimrawan Jember telah berjalan secara efektif. Hal ini dibuktikan dengan adanya peningkatan yang drastis dari pendapatan pada tahun 2017, jika dibandingkan pada tahun 2016 dan 2018 ada kenaikan target pendapatan. 6) Perusahaan menetapkan suatu kebijakan untuk 
memberikan reward dan penishment bagi para manager pusat pertanggungjawaban terhadap kemampuannya dalam mencapai target penjuualan yang telah ditetapkan.

Selain dari kesimpulan dan keterbatasan yang telah dikemukakan diatasnya, peneliti juga memberikan saran diantaranya sebagai berikut: 1) Diharapkan bagi penelitian selanjutnya agar melakukan penelitian berupa observasi secara mendalam agar peneliti mengetahui dengan jelas bagaimana tindakan Pimpinan PDP Kebun Kalimrawan Jember dalam menelusuri lebih lanjut mengenai faktor-faktor internal dan external yang menjadi salah satu penyebab permasalahan pada objek yang diteliti.

\section{Daftar Rujukan}

Adisaputro, Gunawan dan Anggraini, Yunita. 2007. Anggaran Bisnis. Cetakan Pertama. Yogyakarta: Penerbit YPP STIMYKPN.

Anthony, Robert N. dan Govindaraja, Vijay, 2009. Sistem Pengendalian Manejemen. Jilid 1. Jakarta:Salemba Empat.

Anwar, Iyang Sri Anandari. 2013. Pengaruh Penerapan Akuntansi Pertanggungjawaban Terhadap Prestasi Kerja Pada PT. Telkom Witel Jawa Timur (Jember). Skripsi Program Studi Akuntasi Universitas Jember.

Dwijayanti, Arie. 2015. Implementasi Akuntansi Pertanggungjawaban Dalam Penilaian Kinerja Manager Pusat Pendapatan Pada PT. Niaga Nusa Abadi Cabang Jember. Skripsi Program Jurusan Akuntansi Universitas Jember.

Hansen,dan Mowen. 2009. Akuntansi Manejerial. Jakarta: Salemba Empat.

Hansen, Don R, dan Maryanne M. Mowen, 2005 Management Accounting, Edisi Tujuh, Buku Dua, Terjemahan Dewi Fitriasihdan Denny Arnos Kwari. Jakarta: PT. Salemba Empat.

Harrison, Walter T. Horngren, Charles T. Thomas, Bill dan Suwardy, Themin. 2011. Financial Accounting. 8/th-Edition.

Hongren, Charles T dan Datar. 2005. Pengantar Akuntansi Manajemen, Terjemahan Moh. Badjuri dan Drs. Kusnedi, Edisi VI. Jakarta: PT Salemba Empat.

Muharam, Regi 2011. Biaya dan Penilaian Prestasi Kerja. http:/oboutz.wordpress.com/2011/11/18.

Mulyadi. 2004. Akuntansi Manajemen. Akuntansi Manajemen, Konsep, Manfaat dan Rekayasa. Jilid 1. Jakarta: Salemba Empat.

Mulyadi. 2012. Akuntansi Biaya. Edisi Kelima. Cetakan Sebelas. Yogyakarta: BPFE.

Selamat, Ilat, Tiyaroh, Victoria. Z. 2014. Penerapan Akuntansi Pertanggungjawaban Dalam Penilaian Kinerja Pusat Pendapatan Pada PT. Asean Motor International Cabang Manado. Jurnal Emba Vol. 2, No. 2, 2014.

Sriwidodo, Untung. 2010. Informasi Akuntansi Pertanggungjawaban Sebagai Alat Penilaian Prestasi Kerja. Jurnal Akuntansi dan Sistem Teknologi Informasi Vol. 8, No 1, April 2010: 18-14.

Sugiyono. 2013. Metodologi Penelitian Kuantitatif, Kualitatif. dan R\&D. Bandung: Penerbit Alfabeta.

Sugiyono. 2012. Metode Penelitian Administrasi. Cetakan Ke-20. Bandung. Penerbit Alfabeta.

Suwandi. 2008. Peranan Akuntansi Pertanggungjawaban Sebagai Alat Penilaian Prestasi Kerja. Jurnal Logos Vol. 6, No. 1, Juli 2008:55-70.

Viyanti dan Tin, Se. 2010. Akuntansi Pertanggngjawaban Sebagai Alat Pengendalian Manajemen Terhadap Prtestasi Kerja. Jurnal Ilmiah Akuntansi Tahun ke-1, No.3. 